\title{
Reference:
}

1. Hryn', E. L. Polityka rozvytku agrobiznesu v Ukrayini $\mathrm{v}$ napriami zahystu vnutrishniogo prodovolchogo rynku [Agribusiness development policy in Ukraine in the direction of protecting the domestic food market]. Aktualni problem derzhavnogo upravlinnia - Actual problems of public administration. 2009. Vol. 1(35). Pp. 171-178. [in Ukrainian].

2. State Statistics Service of Ukraine. Retrieved from: http://www.ukrstat.gov.ua (accessed on 8 May 2021).

3. Rossokha, V., Sharapa, O. Eksportnyi potentsial agrarnykh pidpryiemstv [Export potential of agricultural enterprises]. Zovnishnia torhivlia: ekonomika, finansy, pravo - Foreign trade: economics, finance, law. 2016. Vol. 4. Pp. 44-63. [in Ukrainian]

Дата подання публікації 08.05.2021p.

УДК 657

Камінська I.M., к.е.н., доцент Kaminska I. Candidate of Economic Sciences, Associate Professor https://orcid.org/0000-0001-6181-7522

Ковальчук Н.В., к.е.н., доцент Kovalchuk N. Candidate of Economic Sciences, Associate Professor https://orcid.org/0000-0001-7621-5882 Демидович А.С., аспірант Demydovych A. Postgraduate Student Горчинська I.П., бакалавр Horchynska I. Bachelor

\section{ТЕОРЕТИКО-МЕТОДИЧНІ ПІДХОДИ ДО АНАЛІЗУ ЕФЕКТИВНОСТІ ДІЯЛЬНОСТІ ПІДПРИЕМСТВА}

\section{Луиький національний технічний університет}

У статті здійснено системне дослідження теоретичних і методичних підходів до аналізу ефективності діяльності підприємства.

На основі аналізу сучасних теоретичних підходів вчених-економістів до розуміння сутності категорії «ефективність діяльності підприємства» виокремлено такі підходи до іiі трактування: економічний підхід; оціночний підхід; затратний підхід; цільовий підхід; фінансовий підхід; комплексний підхід. Трактуючи ефективність діяльності підприємства варто враховувати усі підходи вчених, що дозволить розглядати цю категорію у найширшому значенні.

Базуючись на проведеному дослідженні, доведено, що ефективність діяльності підприємства характеризує його здатність досягати позитивні кількісні та якісні результати від провадження підприємницької діяльності й відповідно досягати визначених цілей при раціональному використані усіх наявних ресурсів.

Встановлено, що категорії «ефективність», «продуктивність», «результативність», «інтенсивність», «економічність», «прибутковість», «доходність», «дієвість», «раціональність» $\epsilon$ самостійними й відмінними, що водночас виражають сукупність параметрів комплексної категорії «ефективність діяльності підприємства».

У статті обгрунтовано сутність та визначено цілі аналізу ефективності діяльності підприємства. Наведено принципи аналізу ефективності діяльності підприємства. Сформовано алгоритм й визначено етапи аналізу ефективності діяльності підприємства.

На основі розгляду сучасних методичних підходів до аналізу ефективності діяльності підприємства встановлено, що відсутній єдиний і універсальний методичний підхід до їі аналізу.

У статті розглянуто зміст і особливості основних методик аналізу ефективності діяльності підприємства. Встановлено, що комплексний, деталізований та усесторонній аналіз ефективності діяльності підприємства повинен охоплювати різноманітні методи та прийоми аналізу.

Резюмуючи методичні підходи науковців до аналізу ефективності діяльності підприємства, у статті систематизовано за групами узагальнюючі і часткові показники.

Доведено, що аналіз ефективності діяльності підприємства $є$ важливим i необхідним інструментом визначення поточного іiі рівня, вивчення резервів підвищення ефективності діяльності суб'єкта господарювання й формування конкретного і адекватного інструментарію нарощення його кінцевих фінансово-економічних результатів. 
Ключові слова: ефективність, результативність, ефективність діяльності підприємства, аналіз ефективності діяльності підприємства.

\title{
THEORETICAL AND METHODOLOGICAL APPROACHES TO THE ANALYSIS OF THE EFFICIENCY OF THE ACTIVITY OF THE ENTERPRISE
}

\author{
Lutsk National Technical University
}

\begin{abstract}
The article provides a systematic study of theoretical and methodological approaches to the analysis of efficiency of the activity of the enterprise.

Based on the consideration of modern theoretical approaches to the understanding the essence of the efficiency of the activity of the enterprise, the following approaches to its interpretation are formed: economic approach; evaluation approach; cost approach; targeted approach; financial approach; integrated approach. Interpreting the efficiency of the enterprise all the approaches of scientists should be taken into account. This approach will alow to consider the category in the broadest sense.

Based on the study it is proved that the efficiency of the activity of the enterprise characterizes its ability to achieve positive quantitative and qualitative results from the implementation of entrepreneurial activity and, accordingly, to achieve certain objectives with the rational use of all available resources.

It is proved that such categories as «efficiency», «productivity», «effectiveness», «intensity», «economy», «profitability», «operability», «rationality» are independent and different categories which at the same time express a set of parameters of the complex category «efficiency of the enterprise».

This article rightly places the essence and defines the objectives of the analysis of the efficiency of the activity of the enterprise. The principles of analysis of the efficiency of the activity of the enterprise are defined. The algorithm for analyzing the financial potential of the enterprise and its stages are developed.

Based on the study of modern methodical approaches to the analysis of the efficiency of the activity of the enterprise, it is established that today there is no a single and universal methodical approach to its analysis.

The article presents the content and features of the main methodical approaches to the analysis of the efficiency of the activity of the enterprise. It is established that a comprehensive, multi-criteria and detailed analysis of the efficiency of the activity of the enterprise should cover a variety of methods and techniques of the analysis.

Summarizing the methodological approaches of scientists to the analysis of the efficiency of the enterprise, the indicators which should be used are systematized and divided into the groups (the generalized and the partial indicators) in the article.

It is proved that the analysis of the efficiency of the activity of the enterprise is a necessary and important tool for determining the current level, studing the reserves of efficiency of economic entities and the formation of specific and adequate tools to create its final financial and economic results.
\end{abstract}

Keywords: efficiency, effectiveness, efficiency of the activity of the enterprise, analysis of the efficiency of the activity of the enterprise.

Постановка проблеми у загальному вигляді i ï̈ зв'язок 3 важливими науковими та практичними завданнями. Необхідною i важливою основою й передумовою успішного функціонування будь-якого підприємства, досягнення ним кінцевої мети, формування довгострокових конкурентних переваг, забезпечення розвитку та приросту вартості суб'єкта господарювання в коротко- і довгостроковій перспективі $\epsilon$ ефективність його діяльності. Так i першочергове значення для прийняття виважених і найбільш доцільних управлінських рішень щодо діяльності та забезпечення стабільного й успішного функціонування підприємства у майбутньому відводиться аналізу ефективності його діяльності. Тому очевидно й беззаперечно, що забезпечення ефективності діяльності підприємства, а також ії підвищення потребують комплексних досліджень теоретичних і методичних аспектів даного питання.

Аналіз останніх досліджень, у яких започатковано вирішення проблеми. Проблематика ефективної діяльності підприємства завжди була актуальною і постійно перебуває у полі зору як економістів-теоретиків, так і економістів-практиків. Вітчизняними та іноземними науковцями й практиками напрацьовано велику кількість методів і підходів до аналізу та забезпечення підвищення ефективності діяльності підприємства, а також сформовану потужну теоретичному базу означеної проблематики. Зокрема, серед науковців слід виділити роботи таких учених, як О.Амоша, Н.Архіпов, І.Балабанов, І.Бланк, І.Бойчик, О.Гетьман, Р.Каплан, 
М.Коваленко, І.Ковальчук, П.Круш, С.Матюх, В.Мец, С.Мочерний, Н.Навольська, В.Отенко, А.Поддєрьогін, С.Покропивний, О.Саленко, Р.Сайфулін, В.Сідун, О.Трут, А.Турило, П.Харів, І.Швець, В.Шаповал, О.Шеремет, Г.Швиданенко, А.Ярославський та багато інших. Разом з тим, незважаючи на значний науковий доробок, у якому представлено різноманітність і неоднозначність теоретичних і методичних підходів навколо проблеми ефективності діяльності підприємства, доречним вбачається синтез, уточнення i узагальнення теоретичних i методичних підходів до дослідження ефективності діяльності підприємства в сучасних умовах національної економіки.

Цілі статті. Цілями статті є системне дослідження теоретичних і методичних підходів до аналізу ефективності діяльності підприємства.

Виклад основного матеріалу дослідження 3 повним обгрунтуванням отриманих наукових результатів. Науково-теоретичні аспекти окресленої проблематики, як зазначалось вище, активно досліджуються вітчизняними й іноземними вченими. Однак, складність і багатоаспектність категорії «ефективність діяльності підприємства» пояснює наявність в сучасній економічній літературі безлічі підходів до розуміння іiі змісту. Ряд авторів розглядають ефективність спрощено, утотожнюючи із отриманим ефектом, що $є$ абсолютним показником, у той час як ефективність - відносний показник. Інші науковці ії пов'язують із результативністю. Однак, результативність характеризує досягнення суб'єктом господарювання певного результату, що може бути не лише позитивним, а й негативним, у той час як ефективність завжди є позитивною величиною, що засвідчує приріст результатів у порівнянні із витраченими ресурсами на їх досягнення. Також є багато прихильників комплексного підходу до трактування цієї категорії, які проблему ефективності діяльності підприємства розглядають і представляють набагато ширше.

Проаналізовані підходи вчених-економістів до розуміння ефективності діяльності підприємства дозволяють стверджувати, що сформувалось декілька підходів до іiі трактування, а саме (табл. 1): економічний підхід; оціночний підхід; затратний підхід; цільовий підхід; фінансовий підхід; комплексний підхід.

Таблиця 1.

Підходи вчених-дослідників до розуміння сутності категорії «ефективність діяльності

Підходи

Економічний підхід

Затратний підхід

Оціночний підхід

Цільовий підхід

Фінансовий підхід

Комплексний Поєднання декількох, або усіх підхід

Ключовий аспект

Ефективність використання ресурсів та і загалом управління ними.

Співвідношення результатів до обсягу витрат.

Співвідношення отриманого результату на одиницю використаних ресурсів.

Здатність досягати поставлених цілей шляхом реалізації раціональних дій

Результативність діяльності підприємства, що проявляється в максимальних результатах за мінімальних витрат. підходів.
Науковці підприємства»

Вахович I.М., Герасимчук 3.В., Камінська І.М. та ін. [1, с. 534]; Ващенко А.А. [2, с. 87]; Воронкова Т.С. [3, с. 50]; Шляга О.В. [4].

Кравченко О.А., Бевзенко Х.С., Бут С.М. [5, с. 74]; Куценко А.В. [6, с. 123]; Ткачук Г.Ю. [7, с. 367]. Близнюк Л.М. [8]; Саленко О.В. [9, с. 65].

Батракова T.I. [10, с. 176]; Полегенька М.А. [11, с. 73]; Лазарева Н.О. [12, с. 18]; Онокало В.Г. [13].

$$
\text { Літвінова В.О. [14, с. 44]. }
$$

Архіпов Н.М. [15, с. 33]; Кравченко О.А., Бевзенко Х.С., Бут С.М. [5, с. 74]; Морщенок Т.С., Біляк О.М. [16]; Отенко В.I. [17, с. 234]; Пилипенко С.М. [18, с. 453, 456]; Тіхонов О.І., Новіков С.В., Тіхонова С.В. [19, с. 788]; Трут О.О., Миколайчук І.П. [20, с. 27]; Шматковська Т.О. [21, с. 117]; Ярославський А.О. [22, с. 174]

Таким чином, ефективність діяльності підприємства $\epsilon$ складною i багатовимірною категорією. На нашу думку, трактуючи ефективність діяльності підприємства варто враховувати усі підходи вчених, що дозволить розглядати цю 
категорію у найширшому значенні. Зважаючи на це, ефективність діяльності niдприємства, як економічну категорію, варто розглядати як його здатність досягати позитивні кількісні та якісні результати від провадження підприємницької діяльності й відповідно досягати визначених цілей при раціональному використані усіх наявних ресурсів.

Варто зауважити, що вчені у своїх публікаціях поряд із категорією «ефективність» вживають такі категорії, як «продуктивність», «результативність», «інтенсивність», «економічність», «прибутковість», «доходність», «дієвість», «раціональність». Вивчивши сутність означених категорій, можна зробити висновок, що усі вони є самостійними відмінними поняттями й водночас виражають сукупність параметрів комплексної категорії «ефективність діяльності підприємства».

Встановивши якісне визначення категорії «ефективність діяльності підприємства», з'ясуємо кількісну іiі визначеність. Узагальнюючи теоретичну базу, можна констатувати що класичним підходом до кількісного визначення розуміння ефективності діяльності підприємства $є$ iї розгляд як співвідношення результату (ефекту) та ресурсів (витрат):

$$
\text { Ефективність }=\frac{\text { Ефект (результат) }}{\text { Витрати (ресурси) }} .
$$

Аналіз ефективності діяльності підприємства - це комплексна аналітична процедура, що здійснюється відповідно до обраної технології та передбачає застосування визначеної сукупності інформативних показників 3 метою якісного, усестороннього і професійного визначення результативності господарської діяльності суб'єкта господарювання загалом і його структурних підрозділів зокрема. виділити:

Серед цілей здійснення аналізу ефективності діяльності підприємства варто підприємства;

-об’єктивне й кваліфіковане встановлення рівня ефективність діяльності

-своєчасне виявлення і врахування факторів, що впливають на ефективність діяльності підприємства; діяльності;

-достовірне й усебічне встановлення сильних і слабких сторін підприємницької

-систематичне підвищення якості управлінських рішень;

-обгрунтоване з'ясування шляхів вирішення виявлених проблем і визначення можливостей підвищення ефективності діяльності підприємства та забезпечення його подальшого розвитку в найближчій і віддаленій перспективі.

Таким чином, аналіз ефективності діяльності підприємства «представляє собою ефективний інструмент інформаційно-аналітичного забезпечення управлінської діяльності підприємства і може бути використаний як для стратегічних, так і для тактичних цілей» [18, с. 454].

Об'єктами такого аналізу є процеси використання різноманітних ресурсів підприємства, операційна, фінансова та інвестиційна його діяльність.

На нашу думку, комплексний аналіз ефективності діяльності підприємства передбачає послідовну реалізацію таких етапів:

1) формулювання мети, уточнення завдань, визначення об'єктів аналізу ефективності діяльності підприємства та складання плану аналітичної роботи;

2) вибір методичного інструментарію і встановлення складу показників ефективності діяльності підприємства;

3) збір необхідної вихідної інформації для організації аналітичних процедур;

4) організація розрахунків показників ефективності діяльності підприємства, аналіз їх динаміки та кількісна оцінка причин зміни;

5) кількісна та якісна інтерпретація отриманих результатів аналізу, виявлення 
тенденцій, сильних і слабких сторін у діяльності підприємства;

6) факторний аналіз ефективності діяльності підприємства та виявлення резервів підвищення ефективності діяльності підприємства, a також можливостей їх практичного застосування;

7) формулювання узагальнюючих висновків щодо рівня ефективності діяльності підприємства;

8) визначення основних орієнтирів подальшого функціонування підприємства та вибір оптимальних сценаріїв підвищення ефективності його діяльності.

Організація аналізу ефективності діяльності підприємства повинна базуватись на сукупності чітко визначених принципів: універсальність, «системність, комплексність, достовірність, об'єктивність, релевантність, оперативність, науковість, зіставлення, адекватність» [23, с. 119].

Аналіз літератури, присвяченій питанням аналізу ефективності діяльності підприємства, показав різноманіття методичних підходів. Також можна знайти й різні методики аналізу ефективності діяльності підприємства (табл. 2). «Сучасний інструментарій оцінки ефективності діяльності підприємств є досить широким: від набору класичних фінансових показників до нових концепцій економічної доданої вартості та збалансованої системи показників» [24, с. 475]. «Кожен 3 підходів не позбавлений недоліків, тому єдності думок з цієї проблеми у світовій економічній теорії та практиці немає» [25, с. 81]. Вчені проводячи аналіз ефективності діяльності підприємства обирають ті методики, які з їх точки зору є простими у застосуванні, інформативними, комплексними та дають достовірні результати. При цьому науковці здійснюють вибір набору різних науково обгрунтованих і інформативних показників.

Таблиця 2.

Методики

Методики аналізу ефективності діяльності підприємства*

Горизонтальний і вертикальний аналіз балансу

Коефіцієнтний аналіз

Порівняльний аналіз

Факторний аналіз

Вартісні методики

Методи експертних бальних оцінок

Методика розрахунку темпових показників

Методика розрахунку показників ділової активності

Методика розрахунку показників рентабельності

Методи оцінки грошових потоків

Інтегральні методи

Передбачає читання аналізу фінансової звітності та, зокрема, дослідження статей балансу в динаміці, а також структури балансу.

Передбачає розрахунок сукупності коефіцієнтів, як відносних величин, які дозволяють робити висновки щодо якісних змін провадження підприємницької діяльності.

Порівнюються кількісні показники підприємства із іншими суб'єктами господарювання, що виступають конкурентами.

Будучи одним із методів деталізації, передбачає детальне дослідження вихідних факторів (показників) на результуючий показник - ефективність діяльності підприємства.

Базуються на встановленні результуючого показника - вартість підприємства - як узагальнюючого критерію ефективності його діяльності.

Передбачає застосування суб'єктивного підходу та бальної оцінки за окремими аспектами ефективності діяльності підприємства.

Передбачає обчислення й аналіз темпових показників із «золотого правила економіки підприємства», що характеризується дотриманням наступних пропорцій: темпи росту прибутку вищі за темпи росту отриманих доходів, що вищі за темпи росту активів підприємства.

Передбачає аналітичне дослідження системи показників ділової активності підприємства, за якими робиться висновок щодо загальної ефективності діяльності підприємства.

Полягає у комплексному аналізі групи відносних показників рентабельності, що узагальнено дозволяють робити висновки щодо ефективності діяльності підприємства.

Передбачають застосування аналітичного інструментарію дисконтування при порівнянні різночасових витрат і доходів підприємства.

Передбачають визначення інтегрального показника, що комплексно й узагальнено характеризує ефективність діяльності підприємства.

* згруповано на основі $[17$, с. $234 ; 9$, с. $65-67 ; 18$, с. $454 ; 25$, с. 83$]$.

«Формування системи показників ефективності господарської діяльності підприємства має: 
- створювати передумови для виявлення резервів росту ефективності;

- відображати витрати всіх видів ресурсів, що споживаються на підприємстві;

- стимулювати використання всіх резервів, наявних на підприємстві;

- виконувати критеріальну функцію» [27].

Резюмуючи методичні підходи науковців до аналізу ефективності діяльності підприємства $[1$, с. $535-536 ; 3$, с. $50 ; 4 ; 7$, с. $372-373 ; 28$, с. $92 ; 29$, с. $79-80 ; 30$, с. $487-$ $488 ; 31$, с. 22-25], вважаємо, варто проводити такий аналіз за групами узагальнюючих і часткових показників, а саме:

1) узагальнюючі показники ефективності діяльності підприємства (рентабельність підприємства, рентабельність продажу, рентабельність продукції, рентабельність власного капіталу, рентабельність активів, темпи росту обсягів виробництва і реалізації продукції, обсяги виробництва і реалізації продукції на 1 грн витрат, зниження витрат на 1 грн товарної продукції, фінансові результати на 1 грн витрат, частка ринку, рівень задоволення потреб ринку та інші);

2) часткові показники ефективності діяльності підприємства:

- показники ефективності використання персоналу (продуктивність праці за виробітком і трудомісткістю, темпи росту продуктивності праці, вивільнення персоналу, економія робочого часу, плинність персоналу, зарплатовіддача, коефіцієнт ефективності використання робочого часу, середньомісячна заробітна плата щодо середнього рівня в державі, економія фонду оплати праці тощо);

- показники ефективності використання фінансових ресурсів (коефіцієнти фінансової стійкості, фінансової стабільності, фінансового ризику, ліквідності та платоспроможності, обсяги капіталовкладень, рентабельність інвестицій, строк окупності інвестицій тощо);

- показники ефективності використання основних засобів (фондовіддача, фондовіддача активної частини основних засобів, фондомісткість, фондоозброєність, рівень придатності основних засобів, рентабельність основних засобів тощо);

- показники ефективності використання оборотних активів (коефіцієнт оборотності активів загалом та їх окремих складових елементів, коефіцієнт завантаження оборотних активів, тривалість одного обороту оборотних активів, рентабельність оборотних активів, вивільнення оборотних активів, приріст фінансових результатів від прискорення оборотності оборотних активів);

- показники ефективності використання матеріальних ресурсів (матеріаломісткість, матеріаловіддача, матеріальні витрати на 1 грн реалізованої продукції, економія / перевитрати матеріальних витрат, частка повторно використаних відходів тощо);

- показники якості продукції (частка продукції, що відповідає світовим i вітчизняним зразкам; відсоток бракованої продукції, втрати від браку, економічний ефект від поліпшення якості продукції тощо).

Висновки. Результати аналізу ефективності діяльності підприємства $є$ вкрай важливими для з'ясування як поточної ситуації, так і для обгрунтованого визначення стратегічних і тактичних планів на майбутнє.

Організація якісного аналізу ефективності діяльності підприємства дозволить:

- забезпечити відповідний рівень ефективності діяльності підприємства через забезпечення ефективності усіх бізнес-процесів, раціональності й ефективності використання усіх видів ресурсів;

- забезпечити цільовий рівень прибутковості діяльності підприємства;

- забезпечити економічний, у тому числі й інноваційний розвиток підприємства у результаті виявлення резервів i напрямів підвищення результативності функціонування суб'єкта господарювання, шляхів його модернізації та капіталізації; 
- сформувати достовірну та комплексну інформаційну основу для раціональної, ефективної, дієвої і гнучкої системи управління ресурсами підприємства та слугуватиме вихідним моментом розробки й реалізації дієвого механізму підвищення ефективності підприємницької діяльності;

- забезпечити розробку й реалізацію на підприємстві перспективних планів, стратегічних й тактичних заходів, спрямованих на підвищення ефективності його діяльності, рівня конкурентоспроможності й економічного розвитку суб'єкта господарювання, а також його подальшого успішного функціонування.

Отже, аналіз ефективності діяльності підприємства є важливим і необхідним інструментом визначення поточного його рівня, вивчення резервів підвищення ефективності діяльності суб'єкта господарювання й формування конкретного і адекватного інструментарію нарощення його кінцевих фінансово-економічних результатів.

\section{Список бібліографічного опису:}

1. Вахович I.М., Герасимчук 3.В., Камінська І.М. та ін. Економіка підприємства: навч. посібник. Луцьк: Надстир'я, $2010.632 \mathrm{c}$.

2. Ващенко А.А. Ефективність виробничо-господарської діяльності в механізмі управління промисловими підприємствами. Економічний вісник. 2014. № 1. С. 80-87.

3. Воронкова Т.Є., Маслюк Л.Л. Підвищення ефективності діяльності підприємств легкої промисловості в умовах ринкових відносин. Інвестиції: практика та досвід. 2016. №20. С. 47-52.

4. Шляга О.В., Гальцев М.В. Шляхи підвищення ефективності роботи підприємства. Вісник 3ДIA. 2014. URL: http://masters.donntu.org/2017/ief/zhyhalova/library/evzdia_7_066.pdf (дата звернення: 05.12.2020).

5. Кравченко О.А., Бевзенко Х.С., Бут С.М. Економічна концепція підвищення ефективності діяльності виробничих підприємств. Економіка: реалії часу. 2015. №5(21). С. 69-76.

6. Куценко А.В. Організаційно-економічний механізм управління ефективністю діяльності підприємств споживчої кооперації України: монографія. Полтава: РВВ ПУСКУ, 2008. 205 с.

7. Ткачук Г.Ю. Підходи до оцінки ефективності господарської діяльності підприємства. Проблеми теорії та методології бухгалтерського обліку, контролю і аналізу. 2015. Вип. 1 (31). С. 366-378.

8. Близнюк Л.М. Підвищення ефективності діяльності підприємства у сфері малого бізнесу. Журнал науковий огляд. 2018. № 2 (45). URL: http://oaji.net/articles/2017/797-1523370573.pdf (дата звернення: 05.12.2020).

9. Саленко О.В. Шляхи визначення ступеню ефективності діяльності підприємства. Економіка та управління підприємствами машинобудівної галузі: проблеми теорії та практики. 2013. № 4 (24). С. 62-71.

10. Батракова Т.І. Сутність поняття «економічна ефективність» діяльності підприємства в ринкових умовах. Науковий вісник Полтавського університету економіки і торгівлі. 2015. № 1 (69). Ч. 1. С. 172-178.

11. Полегенька М.А. Теоретична сутність економічної категорії «ефективність». Агросвіт. 2016. №10. С. 69-74.

12. Лазарева Н.О. Організаційно-економічний механізм управління ефективністю діяльності виробничих підприємств: дис. ... канд. екон. наук: 08.00 .04 «Економіка та управління підприємствами (за видами економічної діяльності)»; Одеська національна академія харчових технологій. Одесca, 2017. URL: https://cardfile.onaft.edu.ua/bitstream/123456789/2989/2/Lazareva.pdf (дата звернення: 28.04.2020).

13. Онокало В.Г. Теоретичні аспекти ефективності діяльності підприємства та підходи до ії оцінки. Економіка $i$ суспільство. 2017. Вип. 13. С. 641-644.

14. Літвінова В.О. Економічна ефективність: сутність та форми. Вісник Бердянського університету менеджменту $i$ бізнесу. 2014. №2. С. 43-45.

15. Архіпов Н.М. Упраління ефективністю операційної діяльності підприємства роздрібної торгівлі: дис. ... к.е.н.: 08.00.04 - економіка та управління підприємствами (за видами економічної діяльності). Київський національний торговельно-економічний університет. Київ, 2019. https://knute.edu.ua/file/Mg==/3bfaacdda3191daf9ae49388890bf830.pdf (дата звернення: 05.12.2020).

16. Морщенок Т.С., Біляк О.М. Огляд підходів до визначення економічної сутності поняття «ефективність». Вісник ЗДІА. 2016. Вип. 1 (01). С. 7-13.

17. Отенко В.І. Формування аналітичного інструментарію оцінки ефективності діяльності підприємства. БІЗНЕСІНФОРМ. 2013. №5. С. 232-237.

18. Пилипенко С.М. Теоретичні засади оцінки ефективності діяльності підприємства. Глобальні та національні проблеми економіки. 2016. Вип. 10. С. 452-456.

19. Тихонов А.И., Новиков С.В., Тихонова С.В. Проведение экономической оценки эффективности деятельности предприятий авиационной промышленности. Московскый экономический журнал. 2019. №12. С. 784-793.

20. Трут О.О., Миколайчук І.П. Ефективність операційної діяльності роздрібного торговельного підприємства та методологія її вимірювання. Науковий вісник Полтавського університету економіки і торгівлі. 2018. №3 (88). С. 2632.

21. Шматковська Т.О., Сосна Г.М. До проблематики підвищення ефективності діяльності підприємства на інноваційних засадах. Фінансовий простір. 2016. № 1 (21). С. 114-118.

22. Ярославський А.О. Економічна ефективність діяльності підприємства: теоретичний аспект. Науковий вісник Ужггородського начіонального університету. 2018. Випуск 20. Ч. 3. С. 174-177. 
23. Чміль Г.Л. Комплексна оцінка ефективності комерційної діяльності підприємств роздрібної торгівлі. Вчені записки ТНУ імені В. І. Вернадського. Серія: Економіка і управління. 2018. №4. Т. 29 (68). С. 117-121.

24. Навольська Н.В. Теоретичні аспекти управління економічною ефективністю діяльності підприємств та вибору показників її оцінки. Економіка і суспільство. 2018. Випуск 18. С. 474-480.

25. Матюх С.А. Дослідження сучасних методів оцінки ефективності діяльності організацій. Економічний аналіз. 2014. T. 15. № 3. С. 79-85.

26. Головенко І.П. Теоретико-методичні підходи до оцінювання економічної ефективності функціонування підприємств. Глобальні та національні проблеми економіки. 2016. Вип. 11. С. 300-303.

27. Левченко Ю.Г., Шекмар Н.А. Методичні підходи до визначення ефективності господарської діяльності підприємства. // Науковий вісник ужгородського університету. Серія «Економіка». Ужгород, 2011. Вип. 32. С. 130136.

URL:

https://dspace.uzhnu.edu.ua/jspui/bitstream/lib/5867/1/МЕТОДИЧНІ\%20ПІДХОДИ\%20ДО\%20ВИЗНАЧЕННЯ\%20ЕФЕ КТИВНОСТІ\%20ГОСПОДАРСЬКОЇ\%20ДІЯЛЬНОСТІ\%20ПІДПРИСМСТВА.pdf (дата звернення: 05.12.2020).

28. Бондарчук О.М., Максимова О.С. Оптимізація ефективності діяльності промислового підприємства гірничої галузі. Економічний вісник. 2018. №1. С. 89-101.

29. Погорєлов С.М., Леденко А.В., Матяж О.А. Дослідження шляхів підвищення ефективності діяльності підприємства. Вісник НТУ «ХПI». 2015. № 26 (1135). С. 76-82.

30. Рубан Л.О., Федорченко Т.О. Методичні засади формування системи показників комплексного аналізу ефективності діяльності промислового підприємства. Молодий вчений. 2017. №6(46). С. 485-489.

31. Архіпов Н.М. Види ефективності операційної діяльності підприємства торгівлі. Науковий вісник Ужгородського національного університету. 2018. Вип. 18. Частина 1. С. 21-26.

\section{References:}

1. Vakhovych, I.M., Herasymchuk, Z.V., Kaminska, I.M. (2016). Business Economics. Lutsk: Nadstyr'ia. 632 p. [in Ukrainian].

2. Vashchenko, A.A. (2014). Efektyvnist vyrobnycho-hospodarskoi diialnosti v mekhanizmi upravlinnia promyslovymy pidpryiemstvamy [The effectiveness of the economic activities in the mechanism of industrial enterprise management]. Ekonomichnyi visnyk, no. 1, pp. 80-87. [in Ukrainian].

3. Voronkova, T.Ye., Masliuk, L.L. (2016). Pidvyshchennia efektyvnosti diialnosti pidpryiemstv lehkoi promyslovosti v umovakh rynkovykh vidnosyn [The efficiency improvement of light industry's enterprises' activity in market relations]. Investytsii: praktyka ta dosvid, no. 20, pp. 47-52.

4. Shliaha, O.V., Haltsev, M.V. (2014). Shliakhy pidvyshchennia efektyvnosti roboty pidpryiemstva [The ways of the enterprise' efficiency increasing]. Visnyk $\quad$ ZDIA. $\quad$ Retrieved from http://masters.donntu.org/2017/ief/zhyhalova/library/evzdia_7_066.pdf (accessed 5 December 2020). [in Ukrainian].

5. Kravchenko, O.A., Bevzenko, Kh.S., But, Ye.M. (2015). Ekonomichna kontseptsiia pidvyshchennia efektyvnosti diialnosti vyrobnychykh pidpryiemstv [The economic concept of increasing the efficiency of industrial enterprises]. Ekonomika: realii chasu, no. 5(21), pp. 69-76. [in Ukrainian].

6. Kutsenko, A.V. (2008). Orhanizatsiino-ekonomichnyi mekhanizm upravlinnia efektyvnistiu diialnosti pidpryiemstv spozhyvchoi kooperatsii Ukrainy [Organizational and economic mechanism of management of efficiency of activity of the enterprises of consumer cooperation of Ukraine. Poltava: RVV PUSKU, 205 p. [in Ukrainian].

7. Tkachuk, H.Yu. (2015). Pidkhody do otsinky efektyvnosti hospodarskoi diialnosti pidpryiemstva [Approaches to assessing the effectiveness of economic activity of the enterprise]. Problemy teorii ta metodolohii bukhhalterskoho obliku, kontroliu i analizu, vol. 1 (31). pp. 366-378. [in Ukrainian].

8. Blyzniuk, L.M. (2018). Pidvyshchennia efektyvnosti diialnosti pidpryiemstva u sferi maloho biznesu [Increasing efficiency of the activity of the enterprise in the field of small business]. Zhurnal naukovyi ohliad, no. 2 (45). Retrieved from http://oaji.net/articles/2017/797-1523370573.pdf (accessed 5 December 2020). [in Ukrainian].

9. Salenko, O.V. (2013). Shliakhy vyznachennia stupeniu efektyvnosti diialnosti pidpryiemstva [Ways of determining the efficiency of enterprises]. Ekonomika ta upravlinnia pidpryiemstvamy mashynobudivnoi haluzi: problemy teorii ta praktyky, no. 4 (24), pp. 62-71. [in Ukrainian].

10. Batrakova, T.I. (2015). Sutnist poniattia «ekonomichna efektyvnist» diialnosti pidpryiemstva v rynkovykh umovakh [Concept of nature «economic efficiency» of the enterprise in market environtment]. Naukovyi visnyk Poltavskoho universytetu ekonomiky i torhivli, no. 1 (69), part 1, pp. 172-178. [in Ukrainian].

11. Polehenka, M.A. (2016). Teoretychna sutnist ekonomichnoi katehorii «efektyvnist» [The theoretical essence of economic categories «efficiency»]. Ahrosvit, no.10, pp. 69-74. [in Ukrainian].

12. Lazareva, N.O. (2017). Organizational and economic mechanism for managing the performance of wineries. Dissertation for the degree of a candidate of economic sciences (doctor of philosophy) in specialty 08.00.04 - Economics and management of enterprises (by kinds of economic activity). Odesa National Academy of Food Technologies, Odesa. Retrieved from https://card-file.onaft.edu.ua/bitstream/123456789/2989/2/Lazareva.pdf (accessed 5 December 2020). [in Ukrainian].

13. Onokalo, V.H. (2017). Teoretychni aspekty efektyvnosti diialnosti pidpryiemstva ta pidkhody do yii otsinky [Theoretical aspects of efficiency of the activity of the enterprise and approaches to its evaluation]. Ekonomika $i$ suspilstvo, vol. 13, pp. 641-644. [in Ukrainian].

14. Litvinova, V.O. (2014). Ekonomichna efektyvnist: sutnist ta formy [Economic efficiency: essence and forms]. Visnyk Berdianskoho universytetu menedzhmentu i biznesu, no. 2, pp. 43-45. [in Ukrainian].

15. Arkhipov, N.M. (2019). Management of efficiency of operational activity of the enterprise of retail trade. Thesis for the candidste degree in Economics in specialty 08.00.04 - Economics and management of Enterprises (by types of economic activity). Kyiv National University of trade and Economics, Kyiv. Retrieved from https://knute.edu.ua/file/Mg==/3bfaacdda3191daf9ae49388890bf830.pdf (accessed 5 December 2020). [in Ukrainian]. 
16. Morshchenok, T.S., Biliak, O.M. (2016). Ohliad pidkhodiv do vyznachennia ekonomichnoi sutnosti poniattia «efektyvnist». [Research of going near determination of economic essence of concept «efficiency»]. Visnyk ZDIA, vol. 1 (01), pp. 7-13. [in Ukrainian].

17. Otenko, V.I. (2013). Formuvannia analitychnoho instrumentariiu otsinky efektyvnosti diialnosti pidpryiemstva [Formation of Analytical Tools of Assessment of Company Effectiveness]. BIZNESINFORM, no. 5, pp. 232-237. [in Ukrainian].

18. Pylypenko, S.M. (2016). Teoretychni zasady otsinky efektyvnosti diialnosti pidpryiemstva [The theoretical aspects of estimating of enterprise activity efficiency]. Hlobalni ta natsionalni problemy ekonomiky, vol. 10, pp. 452-456. [in Ukrainian].

19. Tihonov, A.I., Novikov, S.V., Tikhonova, S.V. (2019). Provedenie ehkonomicheskoj ocenki ehffektivnosti deyatel'nosti predpriyatij aviacionnoj promyshlennosti [Economic evaluation of the efficiency of the activities of the aircraft industry enterprises]. Moskovskij ehkonomicheskij zhurnal, no. 12, pp. 784-793. [in Russian].

20. Trut, O.O., Mykolaichuk, I.P. (2018). Efektyvnist operatsiinoi diialnosti rozdribnoho torhovelnoho pidpryiemstva ta metodolohiia yii vymiriuvannia [Effectiveness of retail trade enterprise operating activity and methodology of its measurement]. Naukovyi visnyk Poltavskoho universytetu ekonomiky i torhivlii, no. 3 (88), pp. 26-32. [in Ukrainian].

21. Shmatkovska, T.O., Sosna, H.M. (2016). Do problematyky pidvyshchennia efektyvnosti diialnosti pidpryiemstva na innovatsiinykh zasadakh [To the problem of the increase of efficiency of activity of the enterprise on innovative principles]. Finansovyi prostir, no. 1 (21), pp. 114-118. [in Ukrainian].

22. Yaroslavskyi, A.O. (2018). Ekonomichna efektyvnist diialnosti pidpryiemstva: teoretychnyi aspekt [Economic efficiency of the business of the enterprise: theoretical aspects]. Naukovyi visnyk Uzhhorodskoho natsionalnoho universytetu, vol. 20, no. 3, pp. 174-177. [in Ukrainian].

23. Chmil, H.L. (2018). Kompleksna otsinka efektyvnosti komertsiinoi diialnosti pidpryiemstv rozdribnoi torhivli [Complex evaluation of efficiency of commercial activity of retail trade enterprises]. Vcheni zapysky TNU imeni V. I. Vernadskoho. Seriia: Ekonomika i upravlinnia, no. 4, issue 29 (68), pp. 117-121. [in Ukrainian].

24. Navolska, N.V. (2018). Teoretychni aspekty upravlinnia ekonomichnoiu efektyvnistiu diialnosti pidpryiemstv ta vyboru pokaznykiv yii otsinky [Theoretical aspects of management of economic efficiency of enterprises and selection of indicators of its evaluation]. Ekonomika i suspilstvo, vol. 18, pp. 474-480. [in Ukrainian].

25. Matiukh, S.A. (2014). Doslidzhennia suchasnykh metodiv otsinky efektyvnosti diialnosti orhanizatsii [Study of existing methods for evaluation of organization activity efficiency]. Ekonomichnyi analiz, vol. 15, no. 3, pp. 79-85. [in Ukrainian].

26. Holovenko, I.P. (2016). Teoretyko-metodychni pidkhody do otsiniuvannia ekonomichnoi efektyvnosti funktsionuvannia pidpryiemstv [Theoretical-methodological approaches to the evaluation of economic efficiency of enterprises]. Hlobalni ta natsionalni problemy ekonomiky, vol. 11, pp. 300-303. [in Ukrainian].

27. Levchenko, Yu.H., Shekmar, N.A. (2011). Metodychni pidkhody do vyznachennia efektyvnosti hospodarskoi diialnosti pidpryiemstva [Approaches to the definition of commercial operations]. Naukovyi visnyk uzhhorodskoho universytetu. Seriia «Ekonomika», $\quad$ vol. $32, \quad$ pp. $130-136 . \quad$ Retrieved $\quad$ from https://dspace.uzhnu.edu.ua/jspui/bitstream/lib/5867/1/МЕТОДИЧНІ\%20ПІДХОДИ\%20ДО\%20ВИЗНАЧЕННЯ\%20ЕФЕ КТИВНОСТІ\%20ГОСПОДАРСЬКОЇ\%20ДІЯЛЬНОСТІ\%20ПІДПРИЄМСТВА.pdf (accessed 5 December 2020). [in Ukrainian].

28. Bondarchuk, O.M., Maksymova, O.S. (2018). Optymizatsiia efektyvnosti diialnosti promyslovoho pidpryiemstva hirnychoi haluzi [Efficiency optimization of industrial mining companies activity]. Ekonomichnyi visnyk, no. 1, pp. 89-101. [in Ukrainian].

29. Pohorielov, S.M., Ledenko, A.V., Matiazh, O.A. (2015). Doslidzhennia shliakhiv pidvyshchennia efektyvnosti diialnosti pidpryiemstva [Research of ways to increase the efficiency of the enterprise]. Visnyk NTU «KhPI», no. 26 (1135), pp. 76-82. [in Ukrainian].

30. Ruban, L.O., Fedorchenko, T.O. (2017). Metodychni zasady formuvannia systemy pokaznykiv kompleksnoho analizu efektyvnosti diialnosti promyslovoho pidpryiemstva [Methodical bases for forming the system of indicators of complex analysis of the efficiency of activity of the industrial enterprise]. Molodyi vchenyi, no. 6(46), pp. 485-489. [in Ukrainian]. 31. Arkhipov, N.M. (2018). Vydy efektyvnosti operatsiinoi diialnosti pidpryiemstva torhivli [Types of efficiency of operating activity of trade enterprise. Naukovyi visnyk Uzhhorodskoho natsionalnoho universytetu, vol. 18, issue 1, pp. 2126. [in Ukrainian].

Дата подання публікації 17.05.2021 p. 